\title{
BIOLOGICAL NOTES ON SPHEX WRIGHTII (CRESSON)
}

\author{
By ChaRles H. Hicks \\ University of Colorado
}

The digger wasp, Sphex wrightii (Cresson), is one of the smallest Sphecids I have yet had an opportunity to study. It was placed in the genus Coloptera by Cresson in 1868. Professor H. T. Fernald has kindly determined this species ${ }^{1}$ for me and gives an account of it in his recent monograph of wasps of the genus Sphex. ${ }^{2}$ My study is based on observations made on the habits and nesting of the female since the male was not taken at all. The wasp was found only rarely at Owens Lake, near Boulder, in August, 1933, although its small size and somewhat concealed hunting habits may have caused this scarcity to appear more evident than actual numbers would warrant. Specimens were seen on different days, hunting among the tumble weeds. Two nests were taken: one, on August 4th; the other, a week later.

The nest of August 11th and the wasp's activity at the time appear more complete and possibly more typical than the earlier record and are given, in part, below. The presence of the nesting wasp was noted by means of a rather loud buzzing the digger made while she was excavating along a road in a field near the lake. She was found at $1: 37$ P. M. and observed continuously until the nest was finished and the wasp captured at $2: 19$. When first found, she had barely begun her vertical tunnel, but was already carrying

${ }^{1}$ Dr. T. D. A. Cockerell examined one specimen and likewise ascribed it to this same species. The writer is pleased to acknowledge this favor.

${ }^{2}$ For a consideration of this species and other Digger wasps of the genus Sphex, see the paper by Professor Fernald entitled "The North American and West Indian Digger Wasps of the Genus Sphex ( $A m$ mophila auct.)." E. O. Painter Printing Co., Deland, Florida. pp. 1-167. Plates I \& II. Figs. 1-39. 1934. 
soil on foot to a definite place some three inches away. This spot continued to be used for soil deposition until the end of the digging. The wasp backed out of the shaft with soil, turned and walked with it in her jaws and fore legs to this spot, released the load, walked back and down the tunnel for more.

This process and sequence continued 91 times between 1:37 and 1:58 P. M., during which time the wasp was not at all distracted from her work. Then, either feeling a need for a brief rest or change of activity, or more probably a solicitude for the safety and welfare of her already captured and suspended prey, she spent some time walking among the branches of one of the several tumble weeds which surrounded her nest and in visiting the moth larva. But the delay lasted only one minute, after which she was back again and digging. The period of excavation ended at 2:03 and the total number of observed loads removed up to this time was 109 . Since she was well started when I arrived, the grand total doubtless was more, but probably not in excess of 125 , or 130 at the most.

This small wasp spent from 2:03 to 2:06 in finding her hidden prey and in bringing it to the nest. She walked over and among the thistle stems, seemingly meeting with some difficulty in locating the larva. This is not surprising, for the branches in this area were exceedingly thick. Reaching the larva resting in the fork of a stem, she grasped it with her jaws on the ventral side back of the true legs, wrapped her fore legs about it and started. It was a green geometrid, long and slender, but larger and heavier than the wasp and bulky in comparison.

The trip to the tunnel was over stems, through and among branches, and the wasp met with minor difficulties on the way. She had to change her hold on the prey a number of times, and on five occasions was forced to turn back and bite or pinch with her jaws the posterior end of the abdomen of the prey. This was due to the fact that it was able to hold onto a stem with its anal legs and with sufficient force, when in a tight place, to momentarily stop the progress of the wasp. Once, after she had been thus hindered, 
she stung it twice on the ventral side of different abdominal segments.

Arriving at the tunnel, she at first walked too swiftly, and moved farther than was necessary so that the head of the larva extended over the tunnel rather than just to or almost to it, as it normally does or should. But she quickly backed up a few millimeters, released the prey, walked down the hole in a journey of inspection, and out. Now she was ready for the provisioning of the cell. She did this by backing into the tunnel, seizing the prey and dragging it slowly out of sight. It took her exactly one minute to arrange the prey and fix her egg to its side.

She spent 12 minutes and 3 seconds, or from 2:07 to $2: 19: 03$, in filling in the tunnel and at other activity about the nest site. Her first act upon emerging from the nest was to find and select a large pebble which was forced well down the shaft. Then she filled in the tunnel with loose soil which she kicked back into it and later tamped. This process continued, although some material was bitten loose nearby. This latter work was necessitated because the soil from earlier digging was not readily available. It had been carried over some stems and had formed a mound, but the stems and debris between it and the tunnel hindered its later use. The digger came several times to heavy pieces of material, such as sticks, clods, small pebbles and the like. These were carried away in her jaws on foot from the nest site and discarded, hence nearly all the material used was fine soil.

When the tunnel was nearly full, she searched long and tirelessly for a large object to finish filling the tunnel and as a blockade to the entrance. She tested many things, but all were rejected, until one finally met her needs. She laboriously carried this in her jaws and forced it well into the nearly filled tunnel. It was not flush with the surface but extended above. Time and again the wasp seized this with her mandibles, and for many seconds at a time pushed and vibrated it. At last, all seemed well to her. This was after she had scraped the surface around the nest site and had left objects scattered about. This was in contrast to her 
earlier careful removal of such material, and resulted in the formation of a camouflage. She next made a few trips out and back (manner of a locality study although no apparent need for it, nor probability of a later return, was seen), then started away and was caught some distance from the nest.

The tunnel was nearly vertical and some $16 \mathrm{~mm}$. long. The cell, at the end and at nearly right angles to the tunnel, contained the prey resting on one side, doubled up so that the posterior and anterior ends nearly met. A small, slender, clear egg about $2 \mathrm{~mm}$. in length was attached to the upper side on the 2nd abdominal segment and near to a spiracle. The prey was able to kick about when stimulated. It was brought home and kept in a test tube, plugged with loose cotton, where further facts were obtained. The digestive tract was cleared of excrement before the egg hatched, and thus better food conditions provided for the wasp larva.

The egg hatched early on August 13, and by the evening of August 17 all the food provided for the larva had been eaten. A day later, its cocoon was well started, and by the evening of the next day it was, from outward appearances, complete. The larva while feeding, and especially at first, fed at the point where the egg had been fastened. It was greenish-yellow in color. The cocoon was photographed, when completed, but the larva within, upon removal from its protective covering and consequent exposure, was too active for picture-taking. It later was less active in its movements and more completely yellow in color. The drawing which accompanies this article was made some five months after the cocoon had been completed and at a time apparently when the insect was hibernating.

Another observation, at the same general location at Owens Lake, affords additional and supplementary facts of behavior. This female dug her vertical tunnel on a flat surface between plants in a soil in which there was some gravel. She produced an audible noise or buzzing as she used her jaws in digging. The loosened soil, held with the inner surface of her head and jaws, front of the thorax and 
legs, was carried up and out of the tunnel as earlier described but, at this nest, only to a distance of $11 / 4$ inches. She carried it out, at a time when the nest was nearly completely dug, at an average rate of five loads each minute.

An intruder, an ant in reality as well as in appearance, came upon the scene soon after observations began on the wasp. The wasp quickly retreated to a distance while the ant entered her nest, moved in and out, in impish fashion. But the wasp did not desert her nest very long. Soon back, she continued the work as before, only perhaps more hurriedly. It seemed that the ant had irritated her, and this later caused her to proceed in a more nervous manner. Her nest, when first found, must have been very nearly complete, for she soon provisioned it.

Her prey was a small greenish larva, which she had left suspended on a plant 18 inches away, hanging over a stem while she was working on the tunnel and cell. She now brought it to the nest, released it with its head to the entrance, backed within and pulled it in after her. This took place in good orthodox fashion, as did also the laying of eggs or the depositing of larvæ by a small tachinid fly just as the prey was disappearing from sight.

She remained in the cell but a few seconds, and upon emerging sought a large pebble to place in the tunnel below the orifice. The first one tried was too small, so she quickly removed it and continued searching for another. She conducted this activity on foot, searching on the ground among the plants near the nest. She soon tried another stone, which again was rejected for like reason as the first.

There followed at this point an interesting fight with a dark ant which was again intruding. The ant literally jumped at the wasp, the latter this time holding her ground and darting back at her foe. The contest continued for a few seconds with little advantage to either. Then each quit voluntarily, or possibly, the wasp was the victor. At any rate, she resumed her work and the ant, as it was scurrying away, was taken for identification.

A suitable pebble was secured, which fitted the upper part of the tunnel, fine soil was kicked in from the surface and 
more was chewed loose from the sides of the opening. The loose soil filler was not great in quantity, and during her activity in securing it, small pebbles found in it were carried away and rejected.

The last phase of tunnel filling and protection consisted first in a diligent search for a large pebble. That she had an object of large size in mind was strongly suggested by the fact that she appeared interested only in the big ones. Too, she brought pebbles three different times and attempted to use larger ones than would fit, before one was

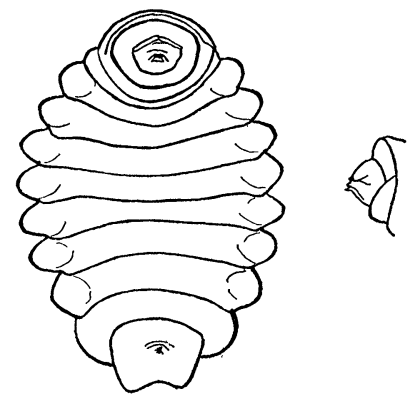

FIG. 1. Ventral view of hibernating larva of Sphex wrightii (Cresson). The head of the entire larva is above. Sketch of side view of head and anterior segment to the right. $\mathrm{X} 6$.

finally approved. It was a large and heavy object, but it fitted into the orifice and to spare, with a portion extending above the surface. She twisted this about in place, and vibrated it vigorously.

At this time another ant, a smaller species this time, bothered her not a little. She soon drove it away, however, and continued with the loose soil or in pushing and vibrating the pebble. A small stem unearthed in obtaining filler was seized in her jaws, carried away and left with the other rubbish of the surrounding area.

The nest filling was quickly finished, and the wasp flew away in and among the branches of tumble weeds where 
from subsequent observation it was thought she finds her prey. She gave evidence at this time of searching for larvæ on the stems. If this be true, she must indeed be a good worker not even to spend some time at rest between one

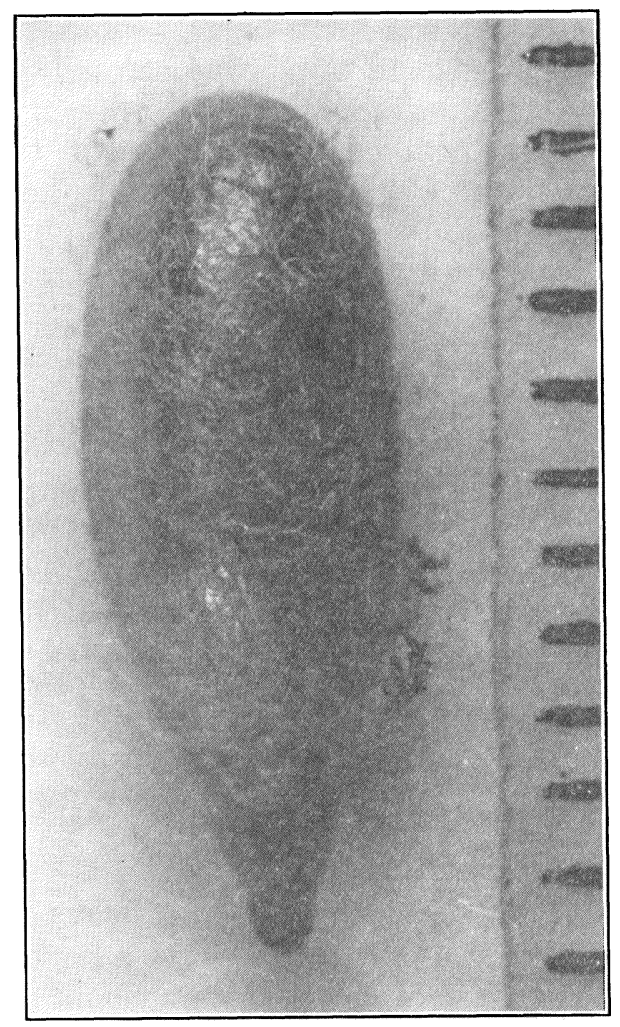

Fig. 2. Cocoon of Sphex wrightii

(Cresson). Millimeter rule marks to the right.

nest provisioning and the hunt and capture of a prey for another. Her capture at this time allowed for no further observations.

The nest was dug out and the prey with an egg attached 
on the lateral surface of an abdominal segment found in a shallow cell not far below the surface. Before the egg had the opportunity or time to hatch in my office at the University, it was found that fly larvæ had taken their toll. Internally, they had eaten the food to the extent that the body walls of the moth larva collapsed and the wasp's egg perished. The identity of the three larvæ, which each formed a puparium, was not learned. In later emerging from the puparia, they crawled into the cotton about them before the body parts were normally expanded and fully developed, thus preventing accurate comparison with normal flies and correct identity.

This wasp species did not use a tool at any time as the tool-users do, although it worked on the large pebble, trying again and again to force it farther into the tunnel and repeatedly vibrating it. This last record, however, is probably not typical and complete, since the ants disturbed the nesting wasp and probably abbreviated many, if not all of her activities.

The larger ant, which troubled the wasp, was taken, and has been compared with determined specimens in the collection of the University of Colorado. It is possibly a variety of Formica fusca L. It was very pugnacious, actually throwing itself at the wasp, which it may have "thought" to be an oversized ant and may have resented its intrusion in this territory. It is possible, too, that the ant was trying to obtain the prey of the wasp as food for its own nest.

The writer is indebted to Charles R. Bitter for the photograph of the cocoon of this wasp and to Louise Ireland for the drawing of the larva. $\mathrm{He}$ is pleased to express his thanks for this help, as also to Professor Fernald for the determination of this wasp and references to this and other digger wasps. 

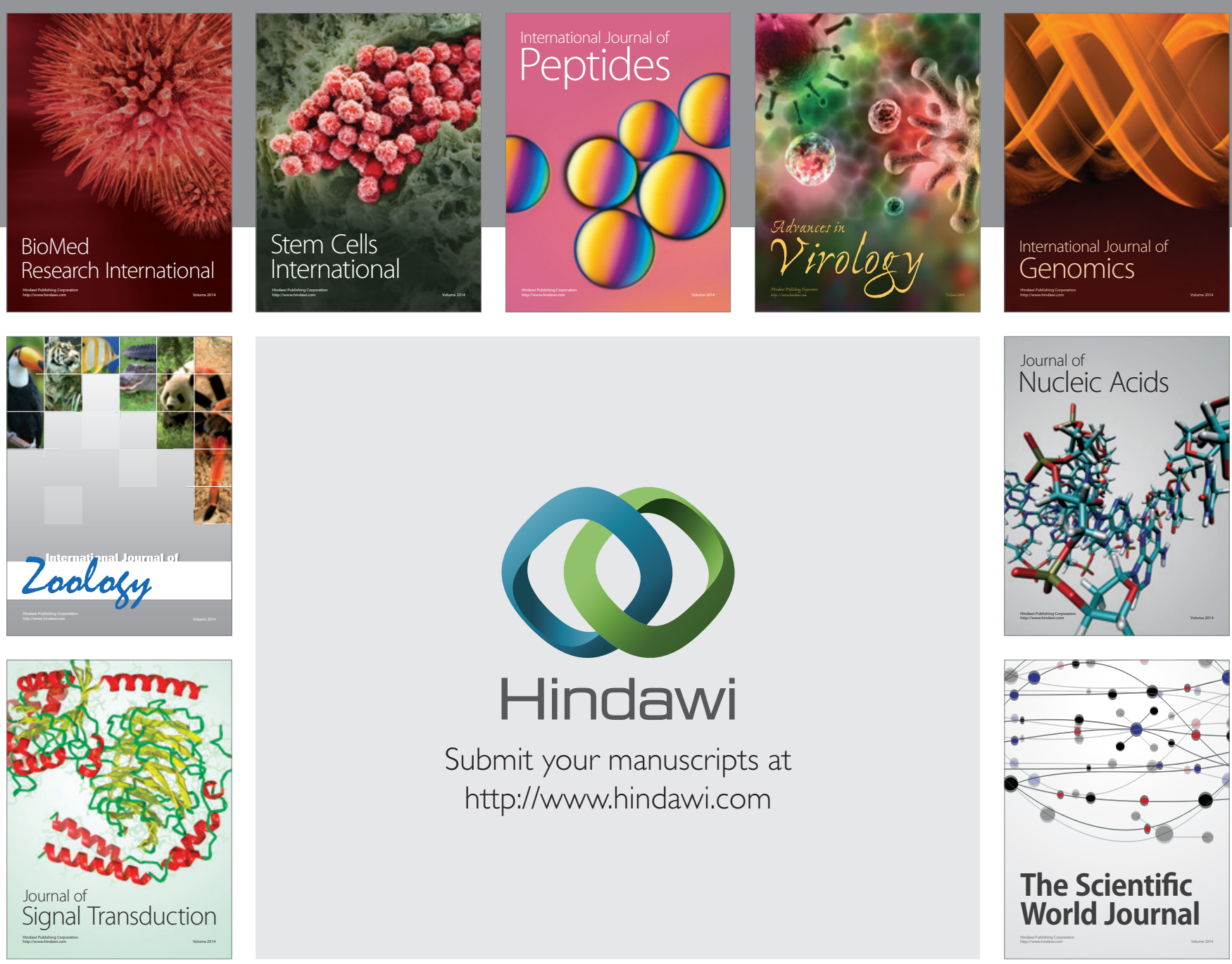

Submit your manuscripts at

http://www.hindawi.com
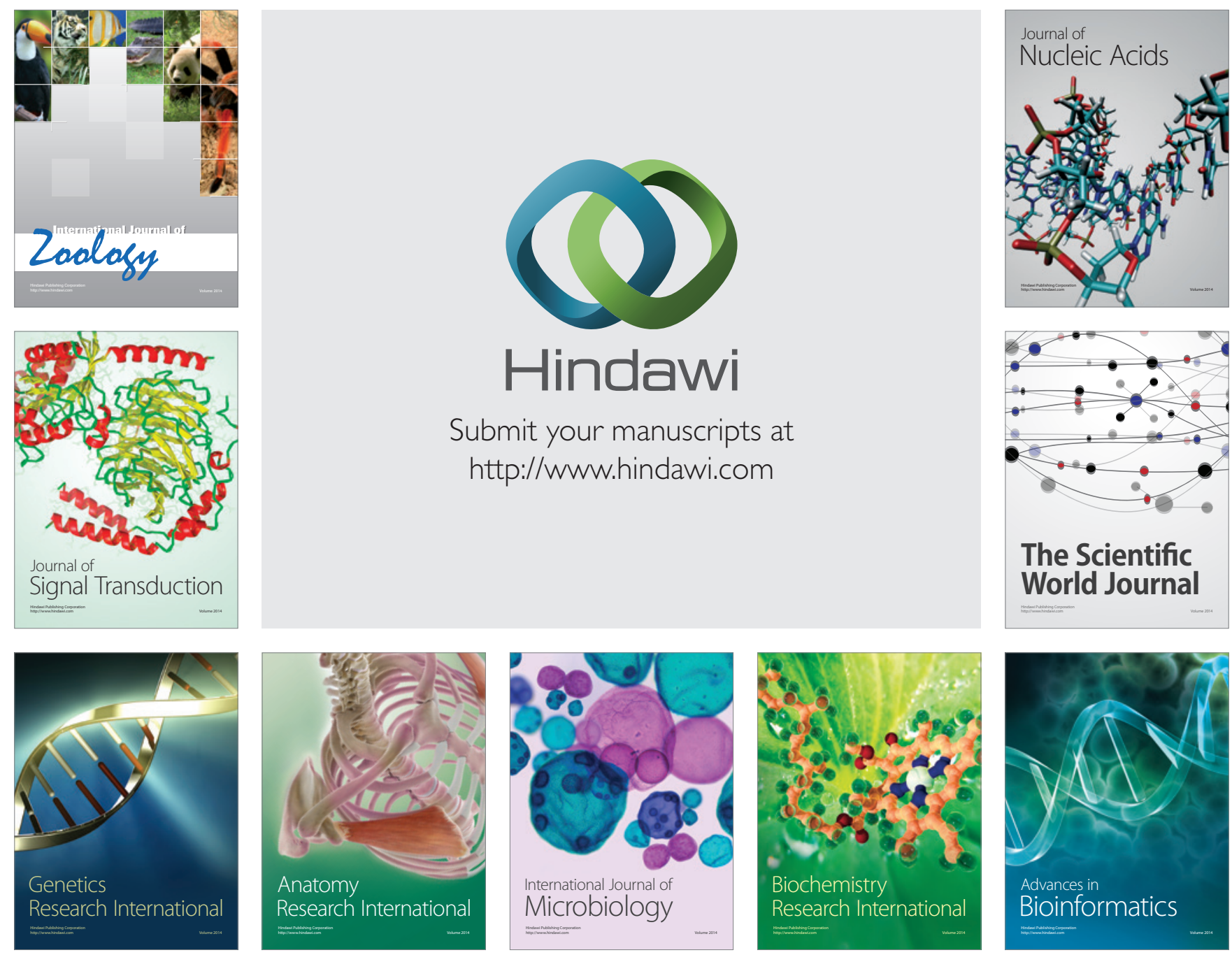

The Scientific World Journal
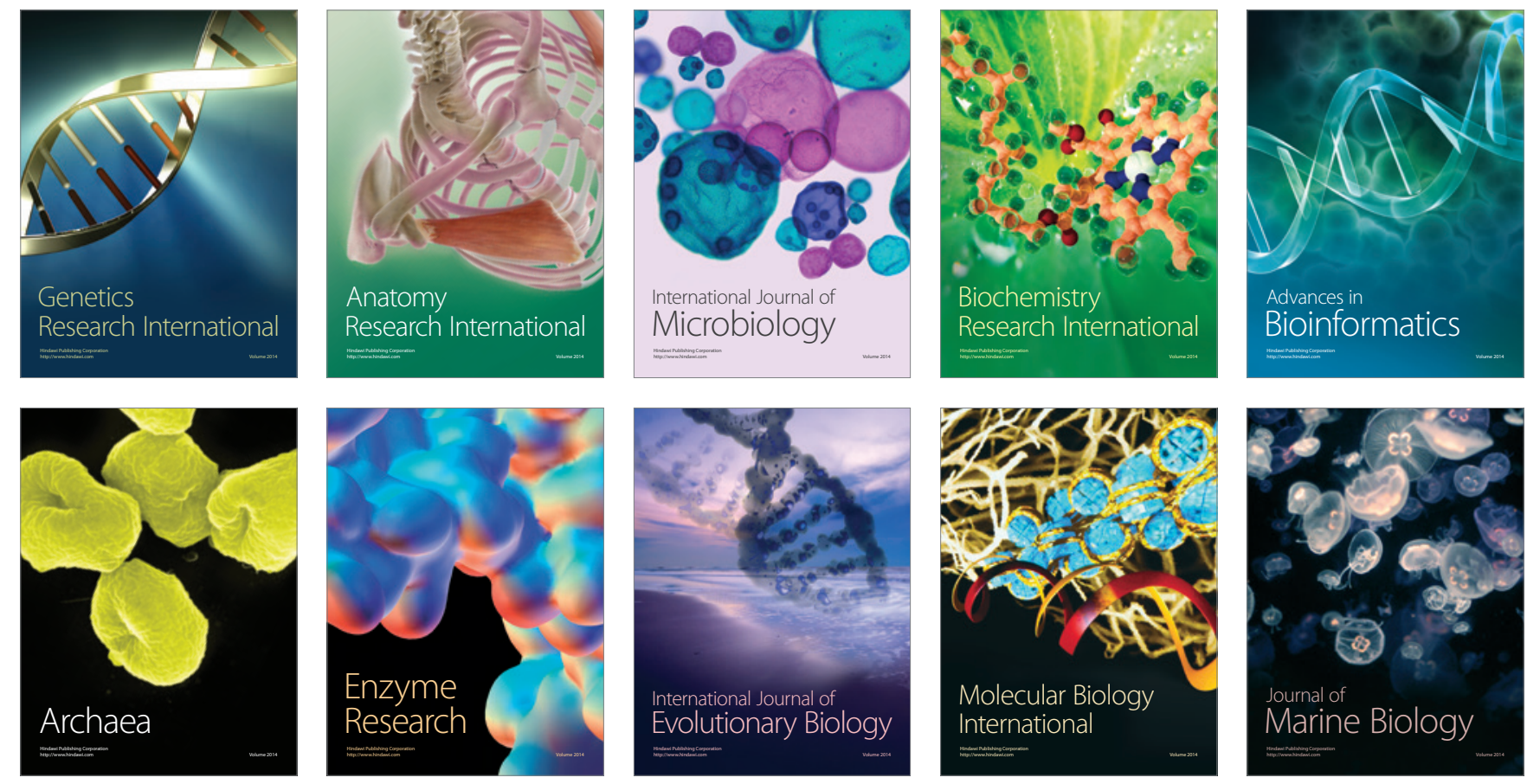